\title{
PROCESS MANAGEMENT AND TOOL SELECTION TO MINIMIZE RISK OF HAND- ARM VIBRATION SYNDROME
}

\author{
Mark B. Geiger, MS, MSE, CIH, CSP* US Navy (OPNAV) Safety Liaison Office \\ Richard Bor cicky, Ergonomist, U.S. Navy Fleet Readiness Center, East, Cherry Point, North Car olina \\ Gavin Burdge, MS, CIH, CSP, BMT Designers and Planners \\ (Supporting the OPNAV Safety Liaison Office) \\ James Chaney, Tools Section Chief, \\ Government Services Administration (GSA), Organizational Code: QSDAAB \\ Steven G. Chervak, MS, CPE, Human Factors Engineer, Ergonomics Program, US Army Public Health \\ Command \\ Ren G. Dong, Ph.D., Center for Disease Control/National Institute for Occupational Safety and Health/HELD \\ Craig M. Henderson, CIH, Code 106.22 Puget Sound Naval Shipyard, Bremerton, Washington \\ Roy Jardin, M.S., Dynamics Research Corp DRC \\ (Project work done working with Robbins Gioia, Inc.) \\ Donald Wasserman, MSEE, MBA, Consultant
}

\section{Introduction}

The Department of Defense (DOD) is among the world's largest maintenance organizations. Many of the processes create high hand-arm vibration exposures and related injury risks during maintenance of defense systems and equipment as well as related activities conducted by DOD contractors, both domestically and abroad. Prolonged exposure can permanently injure the worker resulting in medical treatment costs, retraining costs, and disability payments for the life of the injured party.

As an effort to control the exposure and its related hand-arm vibration syndrome (HAVS), ${ }^{1-4}$ this project was originally resulted from outreach by Craig Henderson, $\mathrm{CIH}$, an industrial hygienist at the Puget Sound Naval Shipyard, who approached the General Services Administration (GSA) for assistance in obtaining lowvibration power hand tools. A representative of the tools section of GSA communicated this issue to the DOD Ergonomics Working Group. ${ }^{5}$ This presentation provided the basis for a project sponsored by the Defense Safety Oversight Council and its Acquisition and Technology Task Force (working group). ${ }^{6}$ DOD also requested GSA collaboration in procurement of low-vibration power hand tools. ${ }^{7}$ Prior to this project, low-vibration characteristics had not been routinely applied to selection criteria for tool procurement. Also, the Federal supply system included no gloves certified by independent parties as meeting the ANSI 2.70/ISO 10819 standards for anti-vibration gloves.

This project is also part of a larger DOD/Navy effort to better integrate safety and health requirements and technology into management of defense acquisition, sustainment and procurement processes. Technical outreach includes education of safety and health professionals in operation of the Defense acquisition and logistics system; application of the system safety process to management of hand arm vibration and influencing process requirements for maintenance and support operations. Initial efforts included publication of a website describing common safety and health hazards associated with operation and maintenance of navy ships, ${ }^{8}$ which included a section on hand arm vibration. ${ }^{9}$ (See www.safetycenter.navy.mil/acquisition). The issue of hand arm vibration as a system safety consideration requiring attention in design and support was communicated as a system safety risk requiring recognition and management at an organization level appropriate to the risk. ${ }^{10}$ Requirements for risk management through a defense systems life cycle, using the standard practice for system safety, ${ }^{11}$ are outlined in DOD acquisition regulations. ${ }^{12}$ This project focuses on application of existing management processes, related education of both safety and health professionals and managers of maintenance and logistics processes, coupled with selective update of available products, low vibration power hand-tools and certified anti-vibration gloves, to minimize the risk of hand arm vibration. The approach is also consistent with the National Occupational Research Agenda (NORA) of the National 
Institute for Occupational Safety and Health (NIOSH) to provide guidance to the entire occupational safety and health community for moving research to practice in workplaces. ${ }^{13}$

\section{Methods}

The Defense Safety Oversight Council in 2007 initiated a project and collaborated with the General Services Administration (GSA) to identify and to incorporate low-vibration power hand tools and gloves certified as meeting the requirements of the ANSI/ISO standards for anti-vibration gloves into the federal procurement process. ${ }^{6,7}$ The project was derived from a collaborative effort between Puget Sound Naval Shipyard and GSA to influence procurement criteria for power hand tools. A working group with DOD/GSA/NIOSH and Coast Guard members was formed. Procurement criteria for anti-vibration gloves, low vibration tools and third party certification guidelines were developed in a meeting hosted by NIOSH in Morgantown, West Virginia in February 2008. The group has continued collaborative efforts and refined the above criteria. An overview of the project was presented to the DOD Industrial Hygiene Forum at the June 2008 American Industrial Hygiene Association Conference. ${ }^{14}$

This project has focused upon identification of processes which create significant exposure risk to hand arm vibration; work with GSA to incorporate vibration (and noise) in procurement criteria for power hand tools and to improve the availability of certified anti-vibration gloves within the Federal supply system. Project contractors included both a logistics management consultant, Robbins Gioia, and an engineer who is one of the world's experts in hand-arm vibration, Don Wasserman. The project differed significantly from other ergonomics and safety evaluations in its initial focus upon integration of process management and coordination with technical process owners.

The project focus was sharing of information among participants, publication of technical information to the safety and health community and outreach to forums not typically linked to the safety and health process.

Education of participants, who were primarily occupational safety and health professionals, focused both upon understanding of the DOD/Federal logistics and acquisition processes and review of information related to hand arm vibration. The agenda of the organizational meeting hosted by NIOSH in Morgantown, West Virginia reflects this balance, Annex 1.

A concurrent effort was made to evaluate available anti-vibration gloves. The two products available in the Federal supply system, both marketed by GSA and described as anti-vibration gloves, were evaluated as unsuitable. Neither conformed to guidelines of the relevant ANSI/ISO Standard. ${ }^{15}$ Product was a "half finger" glove; the other item is classified as a motorcycle glove. The GSA product manager refused to have that item evaluated. Evaluation of product management responsibilities via the Headquarters of the Defense Logistics Agency (DLA) determined that technical responsibility for this category of industrial protective equipment rested with DLA. Coordination with the Defense Supply Center Philadelphia, item manager for this stock class, was also a lengthy and frustrating process. Issues included the complexity for the logistics system which complicated engagement by personnel lacking primary training in logistics, tendency for product managers to rely on existing suppliers with less focus upon alternative sources; regulatory requirements favoring or even requiring American manufactured products; and an organization procurement approach that required customer pre-payment of classification and cataloging costs in the range of $\$ 25,000$ per product. This hindered execution because the contract structure was executed by coordination of a private contractor, Concurrent Technologies Corporation. Acquisition regulations preclude use of Federal funding to pay a private contractor to fund the activities of another Federal entity. Intervention of DLA Headquarters and eventually, OSD Manpower Readiness and Personnel were required to expedite availability of alternative products through the Defense Logistics Information Services. 
A concurrent project to support information outreach included;

- Periodic (approximately monthly) teleconferences with key participants, followed by email distribution of information to all contacts on a growing DOD-wide list. Non-government contacts were included as awareness of the project increased. The current list includes approximately 140 main contacts.

- Development of educational materials for laymen (workers and acquisition/logistics professionals), including a one page brochure (Hand Arm Vibration-just the facts) posted on the Naval Safety Center's website and update of the Safety Center's website.

- Presentations at professional conferences including the American Industrial Hygiene Conference ${ }^{12}$ and National Defense Industries Association. ${ }^{16}$ A half-day workshop was conducted at the Navy Marine Corps Public Health Conference, in March 2009.

- Publications in safety and health forums including the Naval Safety Center's Sea-Shore magazine, ${ }^{17}$ the American Society of Safety Engineers on-line journal ${ }^{18}$ and the DOD Ergonomics Working Group and Defense Readiness Website.

\section{Results}

GSA has incorporated low-vibration and other ergonomic characteristics into their procurement criteria for power hand tools. Three products were available when this abstract was submitted, Table 1. It is anticipated that additional low-vibration tools will be introduced in the immediate future. Continued availability of these products will depend on demand, which must be stimulated through education of management and process owners, as well as development and enforcement of requirements for control of occupational exposures.

\section{Table 1: Currently Available Low Vibration Power Hand Tools}

- $\quad$ Pneumatic riveting hammer, described as HAMMER, PNEUMATIC, PORTABLE 5130-01-5716908. Its vibration $(<2.5 \mathrm{~m} / \mathrm{s} 2)$ is less than half the level created by many legacy tools.

- Pneumatic reciprocating saw, listed as SAW, RECIPROCATING, PNEUMATIC 5130-01-572-5529. Its vibration $(<4 \mathrm{~m} / \mathrm{s} 2)$ is less than half the level created by many legacy tools.

- $\quad$ Needle scaler (needle gun), listed as SCALER, PNEUMATIC, PORTABLE 5130-01-317-2453. To date, GSA has been unable to specify a maximum vibration level for this tool. However, one vendor's product, which served as a guide for the item specification, reportedly had vibration levels in the range of $3.5 \mathrm{~m} / \mathrm{s}$, also considerably lower than many legacy products.

Contacts with varied glove manufactures identified four vendors capable of supplying certified anti-vibration gloves meeting ANSI/ISO 10918 criteria. ${ }^{15}$ Lack of allocated resources (circa \$30,000), procedural delays and apparent intransigence among certain DLA/GSA product managers prevented rapid availability of products with an assigned National Stock Number (NSN). Complex and demanding requirements for "buy American" defense products also complicated rapid product availability. Alternative approaches to providing information to customers requiring these products included

- Development of a list of commercial products distributed as a handout at the DOD Industrial Hygiene Forum at the 2008 American Industrial Hygiene Association Conference and subsequently posted on relevant websites.

- Collaboration with vendors to describe the possibility of listing non-NSN products on the GSA website through the GSA Advantage program (www.GSAadvantage.gov) which permits vendors to list and describe their products via approved distributors. One manufacture of certified anti-vibration gloves took advantage of this alternative.

Eventually, two manufactures, Chase Ergonomics ${ }^{\circledR}$ and Impacto ${ }^{\circledR}$, were able to develop US made products meeting ANSI/ISO 10819 criteria. $^{15}$ Intervention of the Office of the Secretary of Defense (OSD) (Manpower, Personnel and Readiness) was needed support rapid introduction of suitable (certified) antivibration gloves into the Federal supply system. An OSD memo was developed and distributed to support DLA and service procurement of certified anti-vibration gloves. ${ }^{19}$ Notice of their product's availability was accompanied by a model justification supporting use of the more expensive products. 
A brochure and a one-page guide for users of anti-vibration gloves was been developed describing available certified products while listing their national stock numbers.

Several collateral project outcomes and products were developed or implemented as made apparent by the effort. These include;

- NIOSH/Air Force collaboration in evaluation of air frames maintenance/riveting operations at Tinker Air Force Base, to be initiated in approximately April 2010

- Improved tri-service, Coast Guard and private sector collaboration in exchange of information.

- Identification of outdated information in one of the main DOD ergonomics guidance criteria document ${ }^{20}$ and submittal of guidelines for its improvement. ${ }^{21}$

- $\quad$ Liaison with product managers and efforts to integrate improved, low vibration tools into certain processes.

- Initiation of a product deficient report related to anti-vibration gloves which resulted in a funded project to be initiated by the Navy Clothing and Textile Research Facility to evaluate available alternative antivibration gloves, identify research/development needs and possibly fund development of product improvements. Collaboration with NIOSH is anticipated in this area. Project initiation is anticipated in March or April 2010.

A limited proposal for project extension was submitted from the Acquisition and Technology Task Force to the Defense Safety Oversight Council in January 2010. The proposal focus is upon integrating available lowvibration power hand tools into critical DOD maintenance processes. Collateral tasks include providing relevant program guidance, updating policy as necessary and further educational outreach both in hand-arm vibration and process management.

\section{Discussion}

The continued existence of hand-arm vibration syndrome is largely because there is lack of its awareness and the effective implementation of the current standards and available controlling methods ${ }^{22-25}$. Implementation of European standards for evaluation and control of hand arm vibration exposure ${ }^{23}$ have increased the availability of low-vibration power hand tools. Customers in the US market will need to take informed advantage of these products or get "stuck" with the products which will become increasingly difficult to sell in Europe- outdated and more hazardous equipment.

Concurrently, better but obviously, more expensive anti-vibration gloves are now available through the Federal supply system. Demand and continued availability will depend upon effective marketing and enforced requirements for use of suitable products.

Many DOD health and safety professionals are not fully conversant with DOD acquisition, logistics and process management systems. Successful execution of the project required education of industrial hygienists in this complex system. Safety and medical support professionals cannot be successful by simply providing technically appropriate advice; they must be effectively engaged in process management and execution. A contractor knowledgeable in the DOD acquisition system was engaged to support the project. A concurrent process of education for safety and health as well as logistics personnel has made the project successful.

The project's success will ultimately depend on the ability of safety and health professionals to engage the engineering, maintenance, and acquisition authorities responsible for management of specific work-control and maintenance processes, such as riveting and airframes maintenance, tool crib issue, Inspector General evaluation/ inspection criteria, schoolhouse curriculum, etc., and influence the design and support requirements for specific processes and related technical guidance. Efforts also have been made to expand the scope beyond US government boundaries by publicizing the ability of contractors executing government contracts to use the Federal supply system. It is hoped that the very size of the Federal supply system and technical leadership exerted by the associated safety and health professionals may influence product availability and demands for control of a preventable disease. 


\section{References}

1. P. Pelmear and D. Wasserman, Hand-Arm Vibration: A Comprehensive Guide For Occupational Health Professionals', $2^{\text {nd }}$. Edition- (Medical Textbook), OEM Medical Publishers, Beverly Farms, Mass., 1998

2. W. Taylor, D. Wasserman, V. Behrens, S. Samueloff, and D. Reynolds, (1984) Effects of the Air-Hammer On The Hands Of Stonecutters, The Limestone Quarries of Bedford, Indiana Revisited', British Journal of Industrial Medicine, Vol.41, pp. 289-294, Retrieved from http://www.pubmedcentral.nih.gov/articlerender.fcgi?artid=1009311.

3. 'Vibration Syndrome’, Current Intelligence Bulletin \#38., Publication \#83-110, National Institute for Occupational Safety and Health, Cincinnati, Ohio, 1983.

4. Wasserman, D. (1998). What you don't know about occupational vibration can hurt you. Chase Ergonomics. Retrieved from http://www.chaseergo.com/CHASEERG/LITERATE/rsch04.htm.

5. Moran, M. (2005) Procurement Criteria for Low Vibration Power Hand Tools; Presentation to the DOD Ergonomics Working Group (circa February 2005)

6. Geiger, M.B.(2006) Hand-Arm Vibration-Criteria for Tools and Glove Selection Project Proposal submitted to the Defense Safety Oversight Council December 2006

7. Office of the Secretary of Defense (OSD) Personnel and Readiness memo to Government Services Administration of October 31, 2007; Subj: Tool Procurement Criteria to Minimize Risk of Hand Arm Vibration

8. Geiger, M.B., and Bucher, R (2003) Acquisition Safety (overview of the Defense Acquisition System and Safety and Health Issues with a Focus on Ship Systems) http://www.safetycenter.navy.mil/acquisition/index.asp

9. Wasserman, DE. (2003) Acquisition Safety - Vibration (overview of segmental and whole body vibration issues associated with development, maintenance and operation of defense systems) http://www.safetycenter.navy.mil/acquisition/vibration/index.asp

10. Estrada, N., Nowell, J., Harrer, LT K, Wong, A., Lavery, C, Geiger, M.B. (2005) Segmental (Hand/Arm) Vibration as Risk Factor in Systems Design and Development and Support Proceedings of the 23rd International Systems Safety Conference (San Diego, CA) August 2005

11. Military Standard 882D Standard Practice for System Safety, 10 February 2000.

12. Department of Defense Instruction DODI 5000.02 Operation of the Defense Acquisition System December 8, 2008, http://www.dtic.mil/whs/directives/corres/pdf/500002p.pdf

13. The National Occupational Research Agenda (NORA) NIOSH-NORA http://www.cdc.gov/niosh/NORA/about.html

14. Geiger, M.B. (2008) Procurement Criteria to Minimize Risk of Hand Arm Vibration Syndrome, Presentation to the DOD Industrial Hygiene Forum, at the American Industrial Hygiene Association Conference, Minneapolis, MN, June 2008.

.http://www.safetycenter.navy.mil/acquisition/vibration/downloads/Vibration_Talk_DOD_IH_Forum_2008finalJun08.pdf.

15. American National Standard ANSI S2.73-2002 / ISO 10819:1996 (formerly ANSI S3.40-2002 ISO 10819:1996) Reaffirmed by ANSI May 24, 2007: Mechanical Vibration and Shock - Hand-arm vibration - Method for the measurement and evaluation of the vibration transmissibility of gloves at the palm of the hand

16. Geiger, M.B. (2009) Process management and tool selection to minimize risk of hand-arm vibration syndrome, Presentation to the National Defense Industries Association (NDIA) Systems Engineering Conference-October 2629, San Diego, CA (presentation was given by Sherman Forbes, Air Force Staff, Acquisition Management)

17. Geiger, M.B. (2009) Protecting Our People From Bad Vibrations Sea Shore Magazine (Naval Safety Center) Winter 2009-2010 Pages 29-31 http://www.safetycenter.navy.mil/media/seashore/issues/winter09/SeaShoreWinter09-10.pdf

18. Burdge, G., and Geiger, M.B. (2009) Hand-Arm Vibration: Addressing the Hazards. The Monitor, American Society of Safety Engineers (ASSE) on-line publication, Sept 2009, Pages, 1, 28-30 (www.asse.org).

19. Office of the Secretary of Defense (OSD) Manpower Personnel and Readiness (MPR) Memo to Director, Defense Logistics Agency, 15 Dec 2009; Prevention of Vibration Induced Hand-arm Vibration Injury

20. MIL-STD-1472F Department of Defense Design Criteria Standard- Human Engineering, August 23, 1999

21. Geiger, MB (2008) Standardization Document Improvement Proposal for Military Standard 1472, November 2008

22. International Standards Organization: ISO 5349-1986. "Guidelines for the Measurement and the Assessment of Human Exposure to Hand-transmitted Vibration" Revised as ISO5349, Part 1, "General Requirements" and Part 2, "Practical Guidance for the Measurements at the Workplace." Geneva, 2001 to present. 
23. American Conference of Government Industrial Hygienists (ACGIH). "Standard for Hand-Arm Vibration." Cincinnati, 1984 to present.

24. Wasserman, DE, (2006)Hand-Arm Vibration Standards: The New ANSI S2.70 Standard

25. ANSI 2.70 (2006) (replacement of ANSI S3.34): Guide for the Measurement and Evaluation of Human Exposure to Vibration Transmitted to the Hand. New York: American National Standards Institute (ANSI). 